\title{
Review Article \\ The Evolving Treatment Options for Diabetic Macular Edema
}

\author{
Atul Jain, ${ }^{1}$ Neeta Varshney, ${ }^{2}$ and Colin Smith ${ }^{1}$ \\ ${ }^{1}$ San Diego Retina Associates, 7695 Cardinal Court, Suite 100, San Diego, CA 92123, USA \\ ${ }^{2}$ Jules Stein Eye Institute, UCLA School of Medicine, Los Angeles, CA 90095, USA \\ Correspondence should be addressed to Atul Jain; atuljain@stanford.edu
}

Received 26 February 2013; Revised 3 June 2013; Accepted 13 June 2013

Academic Editor: David A. Hollander

Copyright (C) 2013 Atul Jain et al. This is an open access article distributed under the Creative Commons Attribution License, which permits unrestricted use, distribution, and reproduction in any medium, provided the original work is properly cited.

Diabetic retinopathy (DR) is the leading cause of vision loss in working-age adults, and diabetic macular edema (DME) is the most common cause of visual impairment in individuals with DR. This review focuses on the pathophysiology, previous treatment paradigms, and emerging treatment options in the management of DME.

\section{Introduction}

Diabetic retinopathy (DR) is the leading cause of vision loss in working-age adults. In 2002, there were estimated to be just over 13.5 million individuals afflicted with diabetes mellitus (DM) in the USA, or about $6 \%$ of the population. Since then, revised estimates for 2011 indicate that 25.8 million people have DM in the USA, of which 18.8 million are diagnosed and 7 million cases are undiagnosed $[1,2]$. Approximately $28.5 \%$ of individuals with DM have some form of retinopathy; $4.4 \%$ of individuals are at risk of severe vision loss secondary to advanced disease. Present estimates indicate that the incidences of DM and DR are both significantly increasing with as many as 50 million or more individuals in the USA having DM by the year 2050, of which half are expected to have some form of retinopathy [1-5].

DR can be categorized into two broad groups: (1) nonproliferative diabetic retinopathy (NPDR) and (2) proliferative diabetic retinopathy (PDR). Within NPDR, patients are classified as mild, moderate, or severe; severe NPDR is based on at least one of the following findings: diffuse intraretinal hemorrhages in all quadrants, venous beading in at least 2 quadrants, or the presence of intraretinal microvascular abnormalities. Of the two broad categories, proliferative disease, while it is less common, results in more severe vision loss. In nonproliferative disease, the most common cause of vision loss is due to diabetic macular edema (DME). At present, individuals with DR in the USA have a prevalence of DME between 3 and $5 \%$, with this percentage increasing with age [6].
A recent meta-analysis of 35 population-based studies pooling data from the USA, Europe, Asia, and Australia found that in individuals with DM the prevalence of any type of DR is 35\%, with DME present in $7.5 \%$ and PDR present in $7.2 \%$ of individuals. These prevalence rates were found to be significantly higher in individuals with type $1 \mathrm{DM}$ compared to type 2 DM [7]. In the USA, over $90 \%$ of individuals with DM are type 2 diabetics [8].

Summarizing the above data as it applies to the USA, at present, approximately 1.1 million individuals are at serious risk of sight-threatening vision loss from DR. Of these "at risk" individuals, DME is the major etiology of visual impairment or loss with approximately 900,000 individuals with active DME in the USA. A decrease in visual acuity (VA) is commonly used to assess the severity of DME. Fluorescein angiography (FA) has been used extensively to image and assess diabetic eye disease and is useful in the identification of specific areas to treat when using targeted macular laser photocoagulation. More recently, optical coherence tomography (OCT) has become the gold standard used to objectively assess and quantify DME; central macular thickness (CMT) is the most common OCT measurement used for comparative purposes in recent clinical trials. VA outcomes are the focus of this paper.

\section{Inflammation and DME}

DME is due to extracellular swelling typically in Henle's layer of the macula caused by breakdown of the blood-retinal 
barriers [3]. Previously, DME was defined as clinically significant macular edema (CSME) or not, and focal laser treatment was initiated only for CSME (defined as thickening of the retina at or within 500 microns of the center of the macula, hard exudates at or within 500 microns of the center of the macula, if associated with thickening of adjacent retina, or a zone or zones of retinal thickening 1 disc area or larger of which any part is within 1 disc diameter of the center of the macula) [9]. More recently, DME has been subcategorized into two main categories: (1) focal diabetic macular edema (fDME) and (2) diffuse diabetic macular edema (dDME). With advancements in retinal imaging and an increased armamentarium of treatment options, the terms fDME and dDME may be more clinically relevant. Center-involving diabetic macular edema (ciDME) is also now commonly used to describe DME in which the central macula is involved.

As our knowledge of DME has advanced, we now know that the cause is multifactorial. Blood vessel damage plays a significant role in diabetics, both systemically and as related to the development of DME. Long-term hyperglycemia leads to vascular basement membrane thickening, nonenzymatic glycosylation, free radical formation, and pericyte death. These changes ultimately compromise the retinal vascular autoregulatory functioning leading to vascular dilation, increased capillary hydrostatic pressure, and microaneurysm formation [10]. The already weakened capillaries are further compromised due to the inflammatory changes known to occur in diabetics. The retinal vasculature of individuals with DM contains an increased density of leukocytes, which coincides with an increase in expression of ICAM-1 (intercellular adhesion molecule 1), also known as CD54 (cluster of differentiation 54) [11]. ICAM-1 can be induced by interleukin-1 (IL-1) and tumor necrosis factor alpha (TNF- $\alpha$ ). ICAM-1 activation leads to proinflammatory changes and increased vascular permeability due to damage of vascular endothelial cells via a FasL-mediated mechanism leading to further breakdown of the blood-retinal barrier [12] . Numerous cytokines and proinflammatory factors have also been implicated as having a role in DME, the most studied of which is vascular endothelial growth factor (VEGF) [13, 14]. Table 1 lists the inflammatory factors which have been suggested to play a role in DME [15-23].

It is now well known that breakdown of the bloodretinal barrier results from compromised endothelial cell integrity. Osmotic fluctuations, due to hypertension and varying glycemic levels, increased vascular permeability, and capillary dropout, create an environment of inadequate blood flow to the retina. This retinal ischemia leads to the upregulation of VEGF, one of the most potent molecules in causing vascular permeability in humans [11]. VEGF mediates retinal vasculature hyperpermeability by opening endothelial tight junctions and inducing fenestrations. A compromised vascular endothelium secondary to ICAM-1 pathways in conjunction with damage caused by VEGF and other factors in the already weakened diabetic retinal vasculature precipitates a vicious cycle resulting in the inappropriate extravasation of intravascular contents.

While there is significant upregulation of proinflammatory factors in individuals with DME, there is also downregulation of antiinflammatory factors, in particular pigment epithelium derived growth factor (PEDF). Vitreous levels of the following proinflammatory molecules: VEGF, ICAM-1, interleukin-6 (IL-6), and monocyte chemoattractant protein 1 (MCP-1) increase in individuals with DME, while vitreous levels of the antiinflammatory molecule PEDF may be significantly lower in diabetics with severe DME compared to those with only minimal or no DME [24]. Interleukin-8 (IL-8) levels are elevated in the aqueous of individuals with macular edema secondary to diabetes, but not retinovascular occlusive disease. Furthermore, IL-8 levels are not affected by the administration of intravitreal antiVEGF or corticosteroid agents, indicating it could represent a new target in the management of DME [20].

\section{Systemic Conditions and DME}

Duration and control of DM play a major role in the development of DME. Individuals with a longer history of DM are at higher risk of developing DME as well as individuals with poor DM control (higher hemoglobin $\mathrm{A}_{1} \mathrm{C}$ concentrations) $[3,25]$. Optimal hypertensive and DM control can delay and even prevent the onset of DME and vision loss.

The Diabetes Control and Complications Trial (DCCT) evaluated patients with type 1 (insulin dependent) DM for 6.5 years and demonstrated that intensive glycemic control reduced the risk of developing retinopathy by $76 \%(10.7 \%$ versus $33.2 \%$, intensive versus conventional control groups, resp.) in those with no previous retinopathy and slowed the progression of retinopathy by $54 \%$ in those who had mild DR. The conventional group had a hemoglobin $\mathrm{A}_{1} \mathrm{C}$ of 9.1 versus 7.2 in the intensive control group. At the closeout of the DCCT study, 3.9\% (intensive group) versus 7.7\% (conventional group) developed CSME [26-28]. The Epidemiology of Diabetes Interventions and Complications (EDIC) Research Group followed patients for 4 years after conclusion of the DCCT and found that the benefits of intensive diabetes control persisted even with increasing hyperglycemia (hemoglobin $\mathrm{A}_{1} \mathrm{C}$ increased to 7.9 in the intensive group, compared with a reduction to 8.2 in the conventional group). After four years of follow-up in the EDIC study, $18 \%$ of the patients in the intensive-therapy group had a progression in DR compared to $49 \%$ of the patients in the conventional-therapy group. At the closeout of the EDIC study, 3.8\% (intensive group) versus $13.3 \%$ (conventional group) developed CSME [29]. At 10 years after the conclusion of the DCCT study, both intensive and conventional groups had a hemoglobin $\mathrm{A}_{1} \mathrm{C}$ of 8 , with $36 \%$ of patients in the intensive group demonstrating a progression of DR compared to $61 \%$ in the conventional group. In the intensive group, 9\% developed CSME and 8.9\% developed PDR compared to $19 \%$ developing CSME and 24.7\% developing PDR in the conventional group [30].

The United Kingdom Prospective Diabetes Study (UKPDS) studied the effects of glycemic control on type 2 (non-insulin dependent) diabetics and found that intensive glycemic control was associated with a $25 \%$ decrease in microvascular complications and a reduction in the need for macular laser photocoagulation. The UKPDS also found 
TABLE 1: Inflammatory factors suggested to play a role in DME.

\begin{tabular}{|c|c|c|c|}
\hline Reference & Factor & Abbreviation & Clinical relevance \\
\hline$[15]$ & Angiopoietin-1 and 2 & Ang1/Ang2 & Angiogenesis and neovascularization \\
\hline$[16]$ & Erythropoietin & Epo & Stimulates retinal endothelial cell proliferation \\
\hline$[17]$ & Hepatocyte growth factor & HGF & $\begin{array}{l}\text { Stimulate: proliferation, migration, and invasiveness of retinal } \\
\text { endothelial cells }\end{array}$ \\
\hline$[18]$ & $\begin{array}{l}\text { High-sensitivity C-reactive } \\
\text { protein }\end{array}$ & hsCRP & Possibly related to CSME and hard exudation \\
\hline$[19]$ & Insulin-like growth factor-1 & IGF-1 & Angiogenesis \\
\hline$[18]$ & $\begin{array}{l}\text { Intercellular adhesion } \\
\quad \text { molecule } 1\end{array}$ & ICAM-1 & Possibly related to CSME and hard exudation \\
\hline$[20]$ & Interleukin 6 & IL-6 & Vascular permeability \\
\hline$[20]$ & Interleukin 8 & IL-8 & $\begin{array}{l}\text { Mechanism unknown, upregulated in DME but not macular } \\
\text { edema from vascular occlusive disease }\end{array}$ \\
\hline$[20]$ & $\begin{array}{l}\text { Monocyte chemoattractant } \\
\text { protein } 1\end{array}$ & MCP-1 & Leukostasis leading to hypoxia \\
\hline$[21]$ & $\begin{array}{l}\text { Pigment } \\
\text { epithelium-derived factor }\end{array}$ & PEDF & Antiangiogenic and antiinflammatory \\
\hline$[22]$ & Protein kinase $\mathrm{C}$ & $\mathrm{PKC}$ & Increases vascular permeability and contractility \\
\hline$[19]$ & Stromal-derived factor 1 & SDF-1 & Angiogenesis \\
\hline$[23]$ & Thrombospondins 1 and 2 & TSP-1 and 2 & $\begin{array}{l}\text { Anti-angiogenic; inhibit endothelial cell proliferation and } \\
\text { apoptosis }\end{array}$ \\
\hline$[20]$ & $\begin{array}{l}\text { Vascular endothelial } \\
\text { growth factor }\end{array}$ & VEGF & Angiogenesis and vascular permeability \\
\hline
\end{tabular}

that intensive control of blood pressure (BP) had a $34 \%$ reduction in the risk of $\mathrm{DR}$ progression and a $37 \%$ reduction in diabetic microvascular endpoints, such as the need for retinal photocoagulation $[31,32]$.

\section{Laser DME Treatment Paradigms}

Until the early 1980s, there was no intervention available for the treatment of DME. A landmark prospective randomized study performed by the Early Treatment Diabetic Retinopathy Study (ETDRS) group found that grid macular photocoagulation decreased the risk of moderate to severe vision loss from DME by $50 \%$ compared to untreated controls over 3 years [33]. This was the standard of care for over 2 decades. Since the original ETDRS study, there has been evidence to support that a modified ETDRS laser technique has slightly better visual outcomes than a grid pattern of laser alone. In the modified technique, a light macular grid is performed in addition to the targeted treatment of microaneurysms with laser photocoagulation [34].

There is some pieces of evidence that very short duration focal macular laser photocoagulation and subthreshold micropulse diode laser treatments are just as effective as the modified ETDRS method of laser treatment for DME, but with less collateral damage, a lower risk of inducing choroidal neovascularization, and less likelihood of laser wound creep into the central fovea [35-37].

The goal of focal macular laser photocoagulation is preservation of VA and prevention of severe VA loss ( $\geq 15$ ETDRS letters, or 3 Snellen lines of VA) over the long term. Visual acuity gains from focal laser treatment are frequently modest with most studies reporting that $40 \%$ of eyes gain between 0 and 5 ETDRS letters over a two-year period [38-41].

\section{Pharmacological DME Treatment Paradigms}

Corticosteroids were the first pharmacologic intravitreal treatment to be used for DME. Corticosteroids reduce vascular permeability of the retina; while their exact mechanism of action is not completely understood, they reduce production of arachidonic acid derivatives such as prostaglandins as well as inhibiting ICAM-1, TNF- $\alpha$, and VEGF $[3,11,37]$.

Triamcinolone acetonide has been the most widely used and studied corticosteroid in the treatment of DME [39, 42-44]. More recently, other formulations of corticosteroids have been studied and found to be effective in the reduction of DME, including a biodegradable dexamethasone implant (Ozurdex; Allergan, Irvine, CA), a time-released nonbioerodible surgically implantable reservoir of fluocinolone (Retisert; Bausch \& Lomb, Rochester, NY), and a non-bioerodible injectable fluocinolone polymer (Iluvien; Alimera Sciences, Alpharetta, GA) [45-49]. None of the corticosteroids mentioned are currently Food and Drug Administration (FDA) approved for the treatment of DME. Table 2 lists the results of the major studies evaluating corticosteroids for the treatment of DME [39, 43, 46-48, 50].

Intravitreal triamcinolone acetonide has been used for the treatment of DME for a number of years. The effects are often short-lived, requiring frequent retreatment with the main side effects being cataract and glaucoma. In eyes with DME, use of both $2 \mathrm{mg}$ and $4 \mathrm{mg}$ doses resulted in over $50 \%$ 
TABLE 2: Summary of major studies evaluating corticosteroids for DME.

\begin{tabular}{|c|c|c|c|c|c|c|c|c|}
\hline Reference & Study name & Follow-up & Type of DME & Type of study & $\begin{array}{c}\text { Study } \\
\text { methodology }\end{array}$ & $\begin{array}{l}\text { Number of } \\
\text { treatments }\end{array}$ & $\begin{array}{c}\text { Mean ETDRS } \\
\text { letter gains }\end{array}$ & $\begin{array}{c}\text { Number } \\
\text { of eyes }\end{array}$ \\
\hline \multirow{3}{*}{ [39] } & \multirow{3}{*}{$\begin{array}{l}\text { DRCR protocol B: } \\
\text { triamcinolone } \\
\text { versus laser }\end{array}$} & \multirow{3}{*}{36 months } & \multirow{3}{*}{$\begin{array}{l}\text { CMT OCT } \geq \\
250 \mu \mathrm{m} \mathrm{ciDME}\end{array}$} & \multirow{3}{*}{$\begin{array}{l}\text { Prospective, } \\
\text { multicenter }\end{array}$} & Laser alone & 3.1 & 5 & 115 \\
\hline & & & & & $\begin{array}{c}1 \mathrm{mg} \\
\text { triamcinolone }\end{array}$ & $4.2 \mathrm{IVI}$ & 0 & 93 \\
\hline & & & & & $\begin{array}{c}4 \mathrm{mg} \\
\text { triamcinolone }\end{array}$ & $4.1 \mathrm{IVI}$ & 0 & 98 \\
\hline \multirow{2}{*}[43]{} & \multirow{2}{*}{$\begin{array}{l}\text { Triamcinolone } \\
\text { versus placebo for } \\
\text { refractory DME }\end{array}$} & \multirow{2}{*}{24 months } & \multirow{2}{*}{$\begin{array}{l}\text { ciDME after } \geq 1 \\
\text { previous laser } \\
\text { treatment }\end{array}$} & \multirow{2}{*}{$\begin{array}{l}\text { Prospective, } \\
\text { multicenter }\end{array}$} & $\begin{array}{l}\text { Placebo (sham } \\
\text { IVI) }\end{array}$ & N/A & -2.9 & 29 \\
\hline & & & & & $\begin{array}{c}4 \mathrm{mg} \\
\text { Triamcinolone }\end{array}$ & 2.6 & 3.1 & 31 \\
\hline \multirow[b]{2}{*}[46]{} & \multirow[b]{2}{*}{$\begin{array}{l}\text { Intravitreal implant } \\
\text { for DME (Retisert) }\end{array}$} & \multirow[b]{2}{*}{36 months } & \multirow[b]{2}{*}{$\begin{array}{l}\text { CSME after } \geq 1 \\
\text { previous laser }\end{array}$} & \multirow[b]{2}{*}{$\begin{array}{l}\text { Prospective, } \\
\text { multicenter, } \\
\text { Phase } 2\end{array}$} & $\begin{array}{c}0.59 \mathrm{mg} \\
\text { flucinolone } \\
\text { acetonide } \\
\text { surgical implant }\end{array}$ & 1 & $\begin{array}{c}31 \% \geq 15 \text { letter } \\
\quad \text { gain }\end{array}$ & 127 \\
\hline & & & & & $\begin{array}{c}\text { Standard of care } \\
\text { (observation or } \\
\text { laser) } \\
\text { Note: rescue } \\
\text { macular laser } \\
\text { for both groups }\end{array}$ & Not stated & $\begin{array}{c}20 \% \geq \\
\quad \text { gain letter } \\
\quad \text { gain }\end{array}$ & 69 \\
\hline \multirow{4}{*}{ [47] } & \multirow{4}{*}{$\begin{array}{l}{ }^{* *} \text { FAME } \\
\wedge \text { (Iluvien) }\end{array}$} & \multirow{4}{*}{36 months } & \multirow{4}{*}{$\begin{array}{l}\text { CMT OCT } \geq \\
250 \mu \mathrm{m} \text { after } \geq 1 \\
\text { previous laser }\end{array}$} & \multirow{4}{*}{$\begin{array}{l}\text { Prospective, } \\
\text { multicenter }\end{array}$} & $\begin{array}{c}0.5 \mu \mathrm{g} \\
\text { fluocinolone } \\
\text { acetonide } \\
\text { intravitreal } \\
\text { insert }\end{array}$ & $\begin{array}{c}1.3 \text { IVI; } \geq 3 \\
\text { laser in } 3.3 \%\end{array}$ & 7.1 & 270 \\
\hline & & & & & $\begin{array}{c}0.2 \mu \mathrm{g} \\
\text { fluocinolone } \\
\text { acetonide } \\
\text { intravitreal } \\
\text { insert }\end{array}$ & $\begin{array}{c}1.2 \text { IVI; } \geq 3 \\
\text { laser in } 6.6 \%\end{array}$ & 8.1 & 276 \\
\hline & & & & & Sham & $\begin{array}{l}\geq 3 \text { laser in } \\
\quad 11.9 \%\end{array}$ & 3.1 & 126 \\
\hline & & & & & $\begin{array}{l}\text { Note: rescue } \\
\text { macular laser } \\
\text { after week } 6\end{array}$ & & & \\
\hline \multirow{3}{*}{ [49] } & $\begin{array}{l}{ }^{* * *} \text { Dexamethasone } \\
\text { Drug }\end{array}$ & \multirow{3}{*}{6 months } & \multirow{3}{*}{$\begin{array}{l}\text { CSME after } \geq 1 \\
\text { previous laser }\end{array}$} & \multirow{3}{*}{$\begin{array}{l}\text { Prospective, } \\
\text { multicenter, } \\
\text { Phase } 2\end{array}$} & $\begin{array}{c}700 \mu \mathrm{g} \\
\text { dexamethasone } \\
\text { surgical implant }\end{array}$ & 1 & $\begin{array}{l}33.3 \% \geq 10 \\
\text { letter gain }\end{array}$ & 57 \\
\hline & \multirow[t]{2}{*}{$\begin{array}{l}\text { Delivery system in } \\
\text { DME (Ozurdex) }\end{array}$} & & & & $\begin{array}{c}350 \mu \mathrm{g} \\
\text { dexamethasone } \\
\text { surgical implant }\end{array}$ & 1 & $\begin{array}{c}21.1 \% \geq 10 \text { letter } \\
\text { gain }\end{array}$ & 57 \\
\hline & & & & & Observation & N/A & $\begin{array}{c}12.3 \% \geq 10 \text { letter } \\
\text { gain }\end{array}$ & 57 \\
\hline$[50]$ & $\begin{array}{l}\text { Dexamethasone } \\
\text { drug } \\
\text { Delivery system in } \\
\text { vitrectomized } \\
\text { patients }\end{array}$ & 6 months & $\begin{array}{l}\text { CMT OCT } \geq \\
275 \mu \mathrm{m} \text { with } \\
\text { history of } \\
\text { vitrectomy }\end{array}$ & $\begin{array}{l}\text { Prospective, } \\
\text { multicenter, } \\
\text { Phase } 2\end{array}$ & $\begin{array}{c}0.7 \mathrm{mg} \\
\text { dexamethasone } \\
\text { IVI }\end{array}$ & 1 & 3 & 56 \\
\hline
\end{tabular}

"IVI: intravitreal injection.

${ }^{* *}$ Specific number of laser treatments not stated.

${ }^{* * *}$ Specific letter gains not stated.

${ }^{\wedge}$ Trade name of medication used is indicated in parentheses ().

${ }^{\wedge}$ Primary endpoint was day 90 and 10 letter gain. 
of eyes gaining $\geq 10$ ETDRS letters (2 lines of Snellen VA), with the effects lasting for 16 and 20 weeks, respectively [42]. In 2-year follow-up of eyes with DME refractory to macular laser, eyes that received $4 \mathrm{mg}$ of intravitreal triamcinolone acetonide gained 3.1 ETDRS letters compared to a loss of 2.9 ETDRS letters in the placebo group [43]. When comparing 2year VA outcomes of focal macular laser alone to $1 \mathrm{mg}$ versus $4 \mathrm{mg}$ intravitreal injections of triamcinolone acetonide, it was found that laser was superior. Eyes treated with macular laser photocoagulation gained a mean of 2 ETDRS letters compared to a loss of 2 and 4 ETDRS letters in the $1 \mathrm{mg}$ and $4 \mathrm{mg}$ triamcinolone groups, respectively. At 3 years, the laser only group continued to fare better with a gain of 5 ETDRS letters compared to a 0 letter gain in both 1 and $4 \mathrm{mg}$ triamcinolone groups $[39,44]$.

A Phase 2 clinical trial evaluating the safety and efficacy of a $0.59 \mathrm{mg}$ surgically implanted fluocinolone acetonide intravitreal implant (Retisert) in eyes with DME found that VA gains of $\geq 15$ ETDRS letters occurred in $16.8 \%$ of implanted eyes at 6 months and $31.1 \%$ of eyes at 3 years, compared to $1.4 \%$ at 6 months and $20 \%$ at 3 years in the macular laser group. The results were significant at the 6 month time point $(P=0.002)$ but not at 3 years $(P=0.16)$. The incidence of elevated intraocular pressure and cataract formation was much higher in eyes receiving the implant with $33.8 \%$ requiring incisional glaucoma surgery and $91 \%$ requiring cataract extraction compared to $0 \%$ and $20 \%$ in the standard of care group (observation or laser), respectively. Retisert is FDA approved for use in chronic, noninfectious uveitis [46].

A Phase 3 clinical trial evaluating the efficacy and safety of an intravitreally injected fluocinolone acetonide insert (Iluvien) in eyes with DME at low $(0.2 \mu \mathrm{g} / \mathrm{d})$ and high $(0.5 \mu \mathrm{g} / \mathrm{d})$ doses found VA gains at 3 -years of $\geq 15$ ETDRS letters in $33 \%$ and $31.9 \%$ of study eyes, respectively, while $21 \%$ of eyes in the sham injection group had $a \geq 15$ ETDRS letter gain at 3 years $(P=0.030)$. Of treated eyes, $26 \%$ required more than one treatment over the 3 year period. Cataract surgery was required in $83.8 \%$ of eyes in the treatment groups compared to $27.3 \%$ in the sham group. The incidence of elevated intraocular pressure was much higher in the treatment groups with $4.8 \%$ (low dose) and $8.1 \%$ (high dose) of eyes requiring incisional glaucoma surgery compared to $0.5 \%$ in the sham group $[47,48]$. While the $0.2 \mu \mathrm{g} / \mathrm{d}$ dose of Iluvien is approved for use in many European countries (Austria, the United Kingdom, Portugal, France, Germany and Spain), it has yet to be approved for use in the United States.

A Phase 2 clinical trial evaluating the efficacy and safety of a surgically implanted intravitreal dexamethasone delivery system in eyes with DME found that a $700 \mu \mathrm{g}$ dose resulted in VA gains of $\geq 10$ ETDRS letters at 90 days after implantation in $33.3 \%$ of eyes and $30 \%$ of eyes at 180 days. In the $350 \mu \mathrm{g}$ group, $\geq 10$ ETDRS letter gains were seen in $21.1 \%$ and $19 \%$ at 90 and 180 days after implantation, respectively. In the control (observation) group, $\geq 10$ ETDRS letter gains were seen in $12.3 \%$ and $23 \%$ of eyes at 90 and 180 days, respectively. The only statistically significant difference between treatment versus control groups at day 90 was in the $700 \mu$ g treatment group $(P=0.007)$. There was no significant increase in cataract development between treatment and control groups. The treatment group did have a higher incidence of elevated intraocular pressure compared to the control group, but no incisional glaucoma surgery was required in any eyes study [49]. A Phase 3 study of an injectable form of this biodegradable implant (Ozurdex) is currently ongoing.

VEGF-A is believed to be one of the major mediating factors associated with the development of DR and DME. VEGF is a proinflammatory mediator and plays a pivotal role in vascular permeability. It is well known that VEGF levels are higher in diabetic eyes than in normal eyes [51]. At present, there are 4 medications available that target VEGFA: pegaptanib (Macugen; Eyetech Pharmaceuticals, Palm Beach Gardens, FL, USA), bevacizumab (Avastin, Genentech, San Francisco, CA, US), ranibizumab (Lucentis; Genentech, San Francisco, CA, US), and aflibercept (Eylea; Regeneron, Tarrytown, NY) $[40,52,53]$. Table 3 lists the results of the major studies evaluating anti-VEGF agents for the treatment of DME [40, 41, 53-59].

Pegaptanib, a pegylated aptamer that targets the VEGF165 isoform, when administered intravitreally every 6 weeks was found to be more efficacious than macular laser at 24 months, with ETDRS letter gains of 6.1 and 1.3, respectively [52]. Intravitreal bevacizumab, a full-length recombinant humanized antibody against all isoforms of VEGF-A, was found to be more effective than macular laser for persistent ciDME at 24 months, with ETDRS letter gains of 8.5 and -0.5 , respectively [40]. Neither pegaptanib nor bevacizumab is approved by the FDA for the treatment of DME though bevacizumab is widely used for this indication. Pegaptanib is FDA approved for the treatment of neovascular age-related macular degeneration (AMD).

In August 2012, ranibizumab, a recombinant humanized monoclonal antibody fragment that binds all isoforms of VEGF-A, was approved by the FDA for the treatment of DME at the $0.3 \mathrm{mg}$ dose, administered monthly via intravitreal injection. Treatment with ranibizumab resulted in over $39 \%$ of eyes with visually significant DME gaining $\geq 15$ ETDRS letters or more of vision compared to only $18 \%$ of control eyes (which were eligible for macular laser photocoagulation based on protocol specific criteria). The overall gain in VA with monthly ranibizumab injections was 10.9 and 12 ETDRS letters in the $0.3 \mathrm{mg}$ and $0.5 \mathrm{mg}$ groups, respectively, compared to a 2.3 letter gain in the control group. Individuals with a hemoglobin $\mathrm{A}_{1} \mathrm{C}$ level $\leq 8$ had a higher likelihood of a $\geq 15$ letter gain than individuals with higher hemoglobin $\mathrm{A}_{1} \mathrm{C}$ levels. Results were sustained for 24 months with continued treatment [53].

The most recent anti-VEGF agent which has been introduced is aflibercept, previously known as the VEGF-Trap-Eye and is currently approved in the USA for the treatment of neovascular AMD and macular edema secondary to central retinal venous obstruction. Aflibercept binds both VEGFA and placental growth factors 1 and 2, is delivered via intravitreal injection and is currently under study for the treatment of DME. Initial one year results demonstrate that over $40 \%$ of eyes with visually significant DME gained at least 3 lines of vision compared to $11.4 \%$ in the macular laser control group [58]. 
TABLE 3: Summary of major studies evaluating anti-VEGF medications for DME.

\begin{tabular}{|c|c|c|c|c|c|c|c|c|}
\hline Reference & Study name & Follow-up & Type of DME & Type of study & $\begin{array}{c}\text { Study } \\
\text { methodology }\end{array}$ & $\begin{array}{l}\text { Number of } \\
\text { treatments }\end{array}$ & $\begin{array}{c}\text { Mean ETDRS } \\
\text { letter gains }\end{array}$ & $\begin{array}{c}\text { Number } \\
\text { of eyes }\end{array}$ \\
\hline \multirow{4}{*}{ [53] } & \multirow{4}{*}{ RIDE } & \multirow{4}{*}{24 months } & \multirow{4}{*}{$\begin{array}{l}\text { CMT OCT } \geq \\
275 \mu \mathrm{m}\end{array}$} & \multirow{4}{*}{$\begin{array}{l}\text { Prospective, } \\
\text { multicenter, } \\
\text { Phase } 3\end{array}$} & Sham & 1.6 laser & 2.3 & 130 \\
\hline & & & & & $0.3 \mathrm{mg}$ lucentis & $\begin{array}{l}20.5 \text { IVI; } 0.7 \\
\text { laser }\end{array}$ & 10.9 & 125 \\
\hline & & & & & $0.5 \mathrm{mg}$ lucentis & $\begin{array}{l}\text { 21.9 IVI; } 0.3 \\
\text { laser }\end{array}$ & 12 & 127 \\
\hline & & & & & $\begin{array}{c}\text { Note: rescue } \\
\text { laser after } \\
\text { month } 3 \\
\end{array}$ & & & \\
\hline \multirow{4}{*}{ [53] } & \multirow{4}{*}{ RISE } & \multirow{4}{*}{24 months } & \multirow{4}{*}{$\begin{array}{c}\text { CMT OCT } \geq \\
275 \mu \mathrm{m}\end{array}$} & \multirow{4}{*}{$\begin{array}{l}\text { Prospective, } \\
\text { multicenter, } \\
\text { Phase } 3\end{array}$} & Sham & 1.8 laser & 2.6 & 127 \\
\hline & & & & & $0.3 \mathrm{mg}$ lucentis & $\begin{array}{c}21.5 \text { IVI; } 0.8 \\
\text { laser }\end{array}$ & 12.5 & 125 \\
\hline & & & & & $0.5 \mathrm{mg}$ lucentis & $\begin{array}{l}20.9 \text { IVI; } 0.8 \\
\text { laser }\end{array}$ & 11.9 & 125 \\
\hline & & & & & $\begin{array}{c}\text { Note: rescue } \\
\text { laser after } \\
\text { month } 3\end{array}$ & & & \\
\hline \multirow{3}{*}{ [54] } & \multirow{3}{*}{ RESTORE } & \multirow{3}{*}{12 months } & \multirow{3}{*}{$\begin{array}{l}\text { fDME and } \\
\text { dDME }\end{array}$} & \multirow{3}{*}{$\begin{array}{l}\text { Prospective, } \\
\text { multicenter, } \\
\text { Phase } 3\end{array}$} & $\begin{array}{c}\text { lucentis + sham } \\
\text { laser }\end{array}$ & 7 IVI & 6.1 & 116 \\
\hline & & & & & Lucentis + laser & $\begin{array}{l}6.8 \mathrm{IVI} ; 1.7 \\
\text { laser }\end{array}$ & 5.9 & 118 \\
\hline & & & & & $\begin{array}{c}\text { Sham lucentis + } \\
\text { laser }\end{array}$ & 2.1 laser & 0.8 & 111 \\
\hline \multirow{3}{*}{ [55] } & \multirow{3}{*}{ READ-2 } & \multirow{3}{*}{6 months } & \multirow{3}{*}{$\begin{array}{c}\text { CMT OCT } \\
\geq 250 \mu \mathrm{m} \\
\text { dDME and fDME }\end{array}$} & \multirow{3}{*}{$\begin{array}{l}\text { Prospective, } \\
\text { multicenter, } \\
\text { Phase } 2\end{array}$} & Lucentis alone & 4 & 7.2 & 42 \\
\hline & & & & & Laser alone & 1.8 & -0.4 & 42 \\
\hline & & & & & Lucentis + laser & 2 IVI; 2 laser & 3.8 & 42 \\
\hline \multirow{3}{*}[56]{} & \multirow{3}{*}{ READ-2 } & 24 months & $\begin{array}{c}\text { CMT OCT } \geq \\
250 \mu \mathrm{m}\end{array}$ & & Lucentis alone & 9.3 & 7.7 & 33 \\
\hline & & $\begin{array}{l}\text { Above } \\
\text { study [55] } \\
+18 \\
\text { months }\end{array}$ & $\mathrm{dDME}$ and $\mathrm{fDME}$ & $\begin{array}{c}\text { Prospective, } \\
\text { multicenter, } \\
\text { Phase } 2\end{array}$ & $\begin{array}{c}\text { Laser alone; } \\
\text { delayed lucentis }\end{array}$ & $\begin{array}{l}\text { 4.4 IVI; } 1.8 \\
\text { laser }\end{array}$ & 5.1 & 34 \\
\hline & & \multicolumn{2}{|c|}{ +18 months } & & Lucentis + laser & $\begin{array}{l}4.9 \text { IVI; } 2 \\
\text { laser }\end{array}$ & 6.8 & 34 \\
\hline \multirow{3}{*}{ [57] } & \multirow{3}{*}{ RESOLVE } & \multirow{3}{*}{12 months } & \multirow{3}{*}{$\begin{array}{l}\text { CMT OCT } \geq \\
300 \mu \mathrm{m}\end{array}$} & \multirow{3}{*}{$\begin{array}{l}\text { Prospective, } \\
\text { multicenter, } \\
\text { phase } 2\end{array}$} & Lucentis & 10.2 & 10.3 & 102 \\
\hline & & & & & $\begin{array}{l}\text { Sham (no } \\
\text { medication } \\
\text { injected) }\end{array}$ & $\begin{array}{l}8.9 \text { (sham } \\
\text { treatments) }\end{array}$ & -1.4 & 49 \\
\hline & & & & & $\begin{array}{l}\text { Note: rescue } \\
\text { laser for both } \\
\text { groups }\end{array}$ & & & \\
\hline \multirow{3}{*}[58]{} & \multirow{3}{*}{ DA-VINCI } & \multirow{3}{*}{12 months } & \multirow{3}{*}{$\begin{array}{l}\text { CMT OCT } \geq \\
250 \mu \mathrm{m}\end{array}$} & & $\begin{array}{l}\text { Eylea (all arms } \\
\text { combined) }\end{array}$ & $\begin{array}{l}9.3 \text { IVI; } 0.7 \\
\text { laser }\end{array}$ & 9.7 to 13.1 & 175 \\
\hline & & & & $\begin{array}{l}\text { Prospective, } \\
\text { multicenter, }\end{array}$ & Laser alone & 2.5 & -1.3 & 44 \\
\hline & & & & Phase 2 & $\begin{array}{c}\text { Note: rescue } \\
\text { laser after } \\
\text { month } 6 \\
\end{array}$ & & & \\
\hline [59] & $\begin{array}{l}\text { DRCR Protocol } \\
\text { I: lucentis versus }\end{array}$ & 36 months & ciDME & Prospective, & $\begin{array}{l}0.5 \mathrm{mg} \text { lucentis } \\
+ \text { prompt laser }\end{array}$ & $\begin{array}{r}12 \mathrm{IVI} ; \geq 1 \\
\text { laser, } 100 \%\end{array}$ & 6.8 & 144 \\
\hline [39] & $\begin{array}{l}\text { prompt or } \\
\text { deferred laser }\end{array}$ & & & multicenter & $\begin{array}{l}0.5 \text { mg lucentis } \\
+ \text { deferred laser }\end{array}$ & $\begin{array}{l}15 \mathrm{IVI} ; \geq 1 \\
\text { laser, } 46 \%\end{array}$ & 9.7 & 147 \\
\hline
\end{tabular}


TABLe 3: Continued.

\begin{tabular}{|c|c|c|c|c|c|c|c|c|}
\hline Reference & Study name & Follow-up & Type of DME & Type of study & $\begin{array}{c}\text { Study } \\
\text { methodology }\end{array}$ & $\begin{array}{l}\text { Number of } \\
\text { treatments }\end{array}$ & $\begin{array}{c}\text { Mean ETDRS } \\
\text { letter gains }\end{array}$ & $\begin{array}{c}\text { Number } \\
\text { of eyes }\end{array}$ \\
\hline \multirow[b]{2}{*}{ [40] } & \multirow[b]{2}{*}{ BOLT } & \multirow[b]{2}{*}{24 months } & \multirow{2}{*}{$\begin{array}{c}\text { CMT OCT } \geq \\
270 \mu \mathrm{m} \text { persistent } \\
\text { ciDME }\end{array}$} & \multirow{2}{*}{$\begin{array}{l}\text { Prospective, } \\
\text { single center }\end{array}$} & Avastin alone & 13 IVI & 8.6 & 37 \\
\hline & & & & & Laser alone & 4 laser & -0.5 & 28 \\
\hline \multirow{3}{*}[41]{} & \multirow{3}{*}{ PACORS } & \multirow{3}{*}{24 months } & \multirow{3}{*}{$\mathrm{dDME}$} & \multirow{3}{*}{$\begin{array}{l}\text { Retrospective, } \\
\text { multicenter }\end{array}$} & Avastin alone & 5.8 & 11.8 & 141 \\
\hline & & & & & Laser alone & 2.2 & 4.8 & 120 \\
\hline & & & & & Avastin + laser & $\begin{array}{l}6.2 \text { IVI* }^{*} ; 1 \\
\text { laser }\end{array}$ & 8.2 & 157 \\
\hline
\end{tabular}

*IVI: Intravitreal injection.

Given the results from studies with both corticosteroids and anti-VEGF agents, the goal in treatment of DME is now preservation and improvement in VA instead of just maintenance or reduction in the amount of vision loss as was the case with macular laser photocoagulation, the previous standard of care.

\section{Combination Therapy for DME}

Intravitreal pharmacotherapy has replaced macular laser photocoagulation as the gold standard in the care of DME. While it is quite successful in preventing vision loss from DME, and allowing for a significant number of people to realize a gain in VA, the burden of monthly intravitreal injections can become quite an encumbrance for patients, physicians, and the healthcare system as a whole due to high costs of medications, multiple physician visits, and potential complications from an invasive procedure. This has prompted studies to evaluate if combination therapies with both laser and intravitreal injections can be more efficacious than either treatment alone or if combination therapy allows for fewer treatments while maintaining VA gains. A large prospective, randomized, double-blinded study conducted by the Diabetic Retinopathy Clinical Research Network (DRCR) sought to answer this specific question. Eyes with DME were treated with focal macular laser photocoagulation alone, $0.5 \mathrm{mg}$ of monthly ranibizumab + prompt focal macular laser, $0.5 \mathrm{mg}$ of monthly ranibizumab + deferred focal macular laser (after week 24), or $4 \mathrm{mg}$ of quarterly triamcinolone acetonide + prompt focal macular laser. After the first year, intravitreal medications were only administered as needed based on clinical examination. At the end of the 2-year study, it was found that ranibizumab + deferred focal macular laser was the superior treatment algorithm for eyes with visually significant DME. In the ranibizumab + deferred laser group $28 \%$ of eyes gained $\geq 15$ ETDRS (mean gain $=9$ letters); in the ranibizumab + prompt laser group $29 \%$ of eyes gained $\geq 15$ ETDRS letters (mean gain $=8$ letters); a median of 2 and 3 ranibizumab injections were required the second year for the deferred versus prompt groups, respectively. In the laser only group, $18 \%$ of eyes gained $\geq 15$ ETDRS letters with a mean VA gain of 3 letters. In the triamcinolone + laser group, $22 \%$ of eyes gained $\geq 15$ ETDRS letters, with a mean VA gain of 2 letters [60].

A 2-year retrospective study evaluating bevacizumab versus bevacizumab + macular laser versus macular laser alone for eyes with DME found that the bevacizumab only group did better than the other groups with gains of 11.8 ETDRS letters compared to 8.2 and 4.8 ETDRS letter gains, respectively. There was no statistically significant difference between the bevacizumab and bevacizumab + macular laser group, but both these groups were statistically superior to the macular laser only group [61]. The retrospective nature of this study limits the conclusions that can be drawn, and the number of intravitreal treatments in the bevacizumab groups was not indicated.

Anti-VEGF agents have changed how DME is managed providing patients with significant VA gains that are sustainable with repeat injections. Combination therapy is an evolving field and further research is needed to determine how best to care for patients with DME. Given the multifactorial nature of DME, additional studies are necessary to evaluate the role of combination therapy of anti-VEGF agents with corticosteroids in an effort to alleviate the treatment burden of monthly dosing and to assess the efficacy in those individuals with persistent DME despite repeated anti-VEGF therapy. Macular laser photocoagulation still has a role in DME, particularly fDME; however, the optimal timing of when to initiate treatment needs to be further elucidated.

\section{Other and Emerging Treatments for DME}

The vitreous humor has been implicated as a cause of DME due to an increase in the concentration of factors affecting vascular permeability as well as the exertion of tractional forces on the macula [62]. The role of pars plana vitrectomy has been evaluated in the management of DME with mixed results with slightly more eyes gaining $\geq 10$ ETDRS letters than losing the same amount ( 38 and $22 \%$, resp.). The best outcomes were seen in eyes in which starting VA was lower and had an epiretinal membrane present prior to surgery (which was removed at the time of vitrectomy) $[63,64]$.

Use of pharmacologic therapy after vitrectomy in patients with persistent DME remains challenging as clearance of drugs is more rapid in vitrectomized eyes. In a retrospective study of 11 vitrectomized eyes with DME, 3 monthly injections of bevaacizumb had no effect on mean VA or mean foveal thickness [65]. A single intravitreal injection of $0.7 \mathrm{mg}$ dexamethasone (Ozurdex) in previously vitrectomized eyes with persistent DME demonstrated a VA gain of 6 ETDRS letters at week 8 and 3 ETDRS letters at week 26 [50]. In 
a small prospective study evaluating vitrectomy + intravitreal bevacizumab and triamcinolone acetonide versus vitrectomy + intravitreal bevacizumab and triamcinolone acetonide followed by focal macular laser 2 weeks later in eyes with intractable dDME, VA gains of approximately 10 ETDRS letters were realized in both groups 1 year after treatment [66].

Due to the tractional component of the vitreous on the macula, induction of a posterior vitreous detachment (PVD) has shown some modest benefit in those with DME [67]. Ocriplasmin (Jetrea; ThromboGenics, Belgium) has been approved by the FDA for the treatment of vitreomacular adhesion and has some efficacy in inducing a PVD [67]. It is a serine protease which is injected into the vitreous and may have a beneficial role in the treatment for DME. Prospective studies to evaluate this are currently underway.

\section{Conclusion}

There has been an incredible advancement in the treatment of DME over the past 2 decades with the treatment paradigm changing from observation and macular laser photocoagulation to intravitreal pharmacologic therapies of corticosteroids and anti-VEGF agents. Physician and patients are now pursuing gains in VA instead of maintenance or reduction in rate of visual loss from DME.

The future of DME has numerous treatment options available for physicians and patients to not only maintain vision but also improve and maintain sustained VA gains. The future is promising and will likely be comprised of a combination approach utilizing anti-VEGF agents, laser, and corticosteroids designed to address the multifactorial nature of the disease. Thanks to advances in our understanding and increased treatment options for DME, we are now able to better manage this condition for affected patients. While DME was often blinding in the past, we now are able to provide many of our patients with excellent and sustained vision, thereby allowing them to continue to be a part of the workforce. The future is promising, but it must be kept in mind that DM is a systemic disease and optimal glycemic and BP control are of paramount importance in both preventing and delaying the progression of both DR and DME. Communication and a team approach among primary care physicians, endocrinologists, and ophthalmologists will allow patients with DME to achieve and maintain long-term sustained VA gains.

\section{References}

[1] Centers for Disease Control and Prevention, National Diabetes Fact Sheet: National Estimates and General Information on Diabetes and pre Diabetes in the United States, 2011, Department of Health and Human Services, Centers for Disease Control and Prevention, Atlanta, Ga, USA, 2011.

[2] A. Jain, D. Sarraf, and D. Fong, "Preventing diabetic retinopathy through control of systemic factors," Current Opinion in Ophthalmology, vol. 14, no. 6, pp. 389-394, 2003.

[3] M. S. Blumenkranz, "Optimal current and future treatments for diabetic macular oedema," Eye, vol. 24, no. 3, pp. 428-434, 2010.

[4] J. H. Kempen, B. J. O'Colmain, M. C. Leske et al., "The prevalence of diabetic retinopathy among adults in the United
States," Archives of Ophthalmology, vol. 122, no. 4, pp. 552-563, 2004.

[5] K. M. V. Narayan, J. P. Boyle, L. S. Geiss, J. B. Saaddine, and T. J. Thompson, "Impact of recent increase in incidence on future diabetes burden: U.S., 2005-2050," Diabetes Care, vol. 29, no. 9, pp. 2114-2116, 2006.

[6] J. Ding and T. Y. Wong, "Current epidemiology of diabetic retinopathy and diabetic macular edema," Current Diabetes Reports, vol. 12, no. 4, pp. 346-354, 2012.

[7] J. W. Y. Yau, S. L. Rogers, R. Kawasaki et al., "Global prevalence and major risk factors of diabetic retinopathy," Diabetes Care, vol. 35, no. 3, pp. 556-564, 2012.

[8] K. M. V. Narayan, J. P. Boyle, T. J. Thompson, S. W. Sorensen, and D. F. Williamson, "Lifetime risk for diabetes mellitus in the United States," Journal of the American Medical Association, vol. 290, no. 14, pp. 1884-1890, 2003.

[9] Photocoagulation for Diabetic Macular Edema, "Early treatment diabetic retinopathy study report number 1 . Early Treatment Diabetic Retinopathy Study Research Group," Archives of Ophthalmology, vol. 103, no. 12, pp. 1796-1806, 1985.

[10] I. Klaassen, C. J. Van Noorden, and R. O. Schlingemann, "Molecular basis of the inner blood-retinal barrier and its breakdown in diabetic macular edema and other pathological conditions," Progress in Retinal and Eye Research, vol. 34, pp. 1948, 2013.

[11] A. M. Joussen, V. Poulaki, M. L. Le et al., "A central role for inflammation in the pathogenesis of diabetic retinopathy," The FASEB Journal, vol. 18, no. 12, pp. 1450-1452, 2004.

[12] A. M. Joussen, V. Poulaki, N. Mitsiades et al., "Suppression of Fas-FasL-induced endothelial cell apoptosis prevents diabetic blood-retinal barrier breakdown in a model of streptozotocininduced diabetes," The FASEB Journal, vol. 17, no. 1, pp. 76-78, 2003.

[13] R. J. Antcliff and J. Marshall, "The pathogenesis of edema in diabetic maculopathy," Seminars in Ophthalmology, vol. 14, no. 4, pp. 223-232, 1999.

[14] M. J. Tolentino, J. W. Miller, E. S. Gragoudas et al., "Intravitreous injections of vascular endothelial growth factor produce retinal ischemia and microangiopathy in an adult primate," Ophthalmology, vol. 103, no. 11, pp. 1820-1828, 1996.

[15] P. Carmeliet and R. K. Jain, "Molecular mechanisms and clinical applications of angiogenesis," Nature, vol. 473, no. 7347, pp. 298307, 2011.

[16] D. Watanabe, K. Suzuma, S. Matsui et al., "Erythropoietin as a retinal angiogenic factor in proliferative diabetic retinopathy," The New England Journal of Medicine, vol. 353, no. 8, pp. 782792, 2005.

[17] W. Cai, S. L. Rook, Z. Y. Jiang, N. Takahara, and L. P. Aiello, "Mechanisms of hepatocyte growth factor-induced retinal endothelial cell migration and growth," Investigative Ophthalmology and Visual Science, vol. 41, no. 7, pp. 1885-1893, 2000.

[18] R. H. Muni, R. P. Kohly, E. Q. Lee et al., "rospective study of inflammatory biomarkers and risk of diabetic retinopathy in the diabetes control and complications trial," JAMA Ophthalmology, vol. 131, no. 4, pp. 514-521, 2013.

[19] S. Wang, J. K. Park, and E. J. Duh, "Novel targets against retinal angiogenesis in diabetic retinopathy," Current Diabetes Reports, vol. 12, no. 4, pp. 355-363, 2012.

[20] L. A. Owen and M. E. Hartnett, "Soluble mediators of diabetic macular edema: the diagnostic role of aqueous VEGF and cytokine levels in diabetic macular edema," Current Diabetes Reports, vol. 13, no. 4, pp. 476-480, 2013. 
[21] H. Funatsu, H. Noma, T. Mimura, S. Eguchi, and S. Hori, "Association of vitreous inflammatory factors with diabetic macular edema," Ophthalmology, vol. 116, no. 1, pp. 73-79, 2009.

[22] M. Brownlee, "The pathobiology of diabetic complications: a unifying mechanism," Diabetes, vol. 54, no. 6, pp. 1615-1625, 2005.

[23] Y. Wang, S. Wang, and N. Sheibani, "Enhanced proangiogenic signaling in thrombospondin-1-deficient retinal endothelial cells," Microvascular Research, vol. 71, no. 3, pp. 143-151, 2006.

[24] H. Funatsu, H. Noma, T. Mimura, S. Eguchi, and S. Hori, "Association of vitreous inflammatory factors with diabetic macular edema," Ophthalmology, vol. 116, no. 1, pp. 73-79, 2009.

[25] The Diabetes Control and Complications Trial/Epidemiology of Diabetes Interventions and Complications Research Group, "Retinopathy and nephropathy in patients with type 1 diabetes four years after a trial of intensive therapy," The New England Journal of Medicine, vol. 342, no. 6, pp. 381-389, 2000.

[26] The Diabetes Control and Complications Trial Research Group, "The effect of intensive treatment of diabetes on the development and progression of long-term complications in insulindependent diabetes mellitus," The New England Journal of Medicine, vol. 329, no. 14, pp. 977-986, 1993.

[27] The Diabetes Control and Complications Trial, "The effect of intensive diabetes treatment on the progression of diabetic retinopathy in insulin-dependent diabetes mellitus: the diabetes control and complications trial," Archives of Ophthalmology, vol. 113, no. 1, pp. 36-51, 1995.

[28] The Diabetes Control and Complications Trial Research Group, "Progression of retinopathy with intensive versus conventional treatment in the Diabetes Control and Complications Trial," Ophthalmology, vol. 102, no. 4, pp. 647-661, 1995.

[29] The Diabetes Control and Complications Trial and Epidemiology of Diabetes Interventions and Complications Research Group, "Retinopathy and nephropathy in patients with type 1 diabetes four years after a trial of intensive therapy," The New England Journal of Medicine, vol. 342, no. 6, pp. 381-389, 2000.

[30] N. H. White, W. Sun, P. A. Cleary et al., "Prolonged effect of intensive therapy on the risk of retinopathy complications in patients with type 1 diabetes mellitus: 10 years after the Diabetes Control and Complications Trial," Archives of Ophthalmology, vol. 126, no. 12, pp. 1707-1715, 2008.

[31] R. Turner, "Intensive blood-glucose control with sulphonylureas or insulin compared with conventional treatment and risk of complications in patients with type 2 diabetes (UKPDS 33)," The Lancet, vol. 352, no. 9131, pp. 837-853, 1998.

[32] The United Kingdom Prospective Diabetes Study Group, "ETight blood pressure control and risk of macrovascular and microvascular complications in type 2 diabetes: UKPDS 38," British Medical Journal, vol. 317, no. 7160, pp. 703-713, 1999.

[33] Early Treatment Diabetic Retinopathy Study Group, "Photocoagulation for diabetic macular edema. Early treatment diabetic retinopathy study report number 1," Archives of Ophthalmology, vol. 103, no. 12, pp. 1796-1806, 1985.

[34] D. S. Fong, S. F. Strauber, L. P. Aiello et al., "Comparison of the modified early treatment diabetic retinopathy study and mild macular grid laser photocoagulation strategies for diabetic macular edema," Archives of Ophthalmology, vol. 125, no. 4, pp. 469-480, 2007.

[35] A. Jain, J. Collen, A. Kaines, J.-P. Hubschman, and S. Schwartz, "Short-duration focal pattern grid macular photocoagulation for diabetic macular edema: four-month outcomes," Retina, vol. 30, no. 10, pp. 1622-1626, 2010.
[36] S. Sivaprasad, M. Elagouz, D. McHugh, O. Shona, and G. Dorin, "Micropulsed diode laser therapy: evolution and clinical applications," Survey of Ophthalmology, vol. 55, no. 6, pp. 516$530,2010$.

[37] A. J. Witkin and G. C. Brown, "Update on nonsurgical therapy for diabetic macular edema," Current Opinion in Ophthalmology, vol. 22, no. 3, pp. 185-189, 2011.

[38] M. Soheilian, K. H. Garfami, A. Ramezani, M. Yaseri, and G. A. Peyman, "Two-year results of a randomized trial of intravitreal bevacizumab alone or combined with triamcinolone versus laser in diabetic macular edema," Retina, vol. 32, no. 2, pp. 314321, 2012.

[39] Diabetic Retinopathy Clinical Research Network, "Three-year follow-up of a randomized trial comparing focal/grid photocoagulation and intravitreal triamcinolone for diabetic macular edema," Archives of Ophthalmology, vol. 127, no. 3, pp. 245-251, 2009.

[40] R. Rajendram, S. Fraser-Bell, A. Kaines et al., "A 2-year prospective randomized controlled trial of intravitreal bevacizumab or laser therapy (BOLT) in the management of diabetic macular edema: 24-month data: report 3," Archives of Ophthalmology, vol. 130, no. 8, pp. 972-979, 2012.

[41] Pan-American Collaborative Retina Study Group (PACORES), "Intravitreal bevacizumab plus grid laser photocoagulation or intravitreal bevacizumab or grid laser photocoagulation for diffuse diabetic macular edema: results of the Pan-american Collaborative Retina Study Group at 24 months," Retina, vol. 33, no. 2, pp. 403-413, 2013.

[42] F. Audren, A. Lecleire-Collet, A. Erginay et al., "Intravitreal triamcinolone acetonide for diffuse diabetic macular edema: phase 2 trial comparing $4 \mathrm{mg}$ vs $2 \mathrm{mg}$," American Journal of Ophthalmology, vol. 142, no. 5, pp. 794.e8-799.e8, 2006.

[43] M. C. Gillies, F. K. P. Sutter, J. M. Simpson, J. Larsson, H. Ali, and M. Zhu, "Intravitreal triamcinolone for refractory diabetic macular edema. Two-year results of a double-masked, placebocontrolled, randomized clinical trial," Ophthalmology, vol. 113, no. 9, pp. 1533-1538, 2006.

[44] Diabetic Retinopathy Clinical Research Network, "A randomized trial comparing intravitreal triamcinolone acetonide and focal/grid photocoagulation for diabetic macular edema," Ophthalmology, vol. 115, no. 9, pp. 1447-1449, 2008.

[45] B. D. Kuppermann, M. S. Blumenkranz, J. A. Haller et al., "Randomized controlled study of an intravitreous dexamethasone drug delivery system in patients with persistent macular edema," Archives of Ophthalmology, vol. 125, no. 3, pp. 309-317, 2007.

[46] P. A. Pearson, T. L. Comstock, M. Ip et al., "Fluocinolone acetonide intravitreal implant for diabetic macular edema: a 3-year multicenter, randomized, controlled clinical trial," Ophthalmology, vol. 118, no. 8, pp. 1580-1587, 2011.

[47] FAME Study Group, "Sustained delivery fluocinolone acetonide vitreous inserts provide benefit for at least 3 years in patients with diabetic macular edema," Ophthalmology, vol. 119, no. 10, pp. 2125-2132, 2012.

[48] P. A. Campochiaro, G. Hafiz, S. M. Shah et al., "Sustained ocular delivery of fluocinolone acetonide by an intravitreal insert," Ophthalmology, vol. 117, no. 7, pp. 1393-1399, 2010.

[49] J. A. Haller, B. D. Kuppermann, M. S. Blumenkranz et al., "Randomized controlled trial of an intravitreous dexamethasone drug delivery system in patients with diabetic macular edema," Archives of Ophthalmology, vol. 128, no. 3, pp. 289-296, 2010.

[50] Ozurdex CHAMPLAIN Study Group, "Dexamethasone intravitreal implant for treatment of diabetic macular edema in vitrectomized patients," Retina, vol. 31, no. 5, pp. 915-923, 2011. 
[51] L. P. Aiello, R. L. Avery, P. G. Arrigg et al., "Vascular endothelial growth factor in ocular fluid of patients with diabetic retinopathy and other retinal disorders," The New England Journal of Medicine, vol. 331, no. 22, pp. 1480-1487, 1994.

[52] Macugen 1013 Study Group, "A phase 2/3, multicenter, randomized, double-masked, 2-year trial of pegaptanib sodium for the treatment of diabetic macular edema," Ophthalmology, vol. 118, no. 6, pp. 1107-1118, 2011.

[53] RISE and RIDE Research Group, "Ranibizumab for diabetic macular edema: results from 2 phase iii randomized trials: RISE and RIDE," Ophthalmology, vol. 119, no. 4, pp. 789-801, 2012.

[54] RESTORE Study Group, "The restore study: ranibizumab monotherapy or combined with laser versus laser monotherapy for diabetic macular edema," Evidence-Based Ophthalmology, vol. 12, no. 4, pp. 206-207, 2011.

[55] READ-2 Study Group, "Primary end point (Six Months) results of the ranibizumab for edema of the macula in diabetes (READ2) study," Ophthalmology, vol. 116, no. 11, pp. 2175-2181, 2009.

[56] READ-2 Study Group, "Two-year outcomes of the ranibizumab for edema of the macula in diabetes (READ-2) study," Ophthalmology, vol. 117, no. 11, pp. 2146-2151, 2010.

[57] P. Massin, F. Bandello, J. G. Garweg et al., "Safety and efficacy of ranibizumab in diabetic macular edema (RESOLVE study): a 12-month, randomized, controlled, double-masked, multicenter phase II study," Diabetes Care, vol. 33, no. 11, pp. 2399-2405, 2010.

[58] DA VINCI Study Group, "One-year outcomes of the DA VINCI study of VEGF trap-eye in eyes with diabetic macular edema," Ophthalmology, vol. 119, no. 8, pp. 1658-1665, 2012.

[59] Diabetic Retinopathy Clinical Research Network, "Intravitreal ranibizumab for diabetic macular edema with prompt versus deferred laser treatment: three-year randomized trial results," Ophthalmology, vol. 119, no. 11, pp. 2312-2318, 2012.

[60] Diabetic Retinopathy Clinical Research Network, "Expanded 2year follow-up of ranibizumab plus prompt or deferred laser or triamcinolone plus prompt laser for diabetic macular edema," Ophthalmology, vol. 118, no. 4, pp. 609-614, 2011.

[61] Pan-American Collaborative Retina Study Group (PACORES), "Comparison of two doses of primary intravitreal bevacizumab (Avastin) for diffuse diabetic macular edema: results from the Pan-American Collaborative Retina Study Group (PACORES) at 12-month follow-up," Graefe's Archive for Clinical and Experimental Ophthalmology, vol. 247, no. 6, pp. 735-743, 2009.

[62] J. W. Harbour, W. E. Smiddy, H. W. Flynn Jr., and P. E. Rubsamen, "Vitrectomy for diabetic macular edema associated with a thickened and taut posterior hyaloid membrane," American Journal of Ophthalmology, vol. 121, no. 4, pp. 405-413, 1996.

[63] Diabetic Retinopathy Clinical Research Network Writing Committee, "Vitrectomy outcomes in eyes with diabetic macular edema and vitreomacular traction," Ophthalmology, vol. 117, no. 6, pp. 1087.e3-1093.e3, 2010.

[64] C. J. Flaxel, A. R. Edwards, L. P. Aiello et al., "Factors associated with visual acuity outcomes after vitrectomy for diabetic macular edema: diabetic retinopathy clinical research network," Retina, vol. 30, no. 9, pp. 1488-1495, 2010.

[65] A. Yanyali, B. Aytug, F. Horozoglu, and A. F. Nohutcu, "Bevacizumab (Avastin) for diabetic macular edema in previously vitrectomized eyes," American Journal of Ophthalmology, vol. 144, no. 1, pp. 124-126, 2007.

[66] A. M. Saeed, "Combined vitrectomy and intravitreal injection versus combined laser and injection for treatment of intractable diffuse diabetic macular edema," Journal of Clinical Ophthalmology, vol. 7, pp. 283-297, 2013.
[67] F. Lopez-Lopez, M. Rodriguez-Blanco, F. Gómez-Ulla, and J. Marticonera, "Enzymatic vitreolysis," Current Diabetes Reviews, vol. 5, no. 1, pp. 57-62, 2009. 


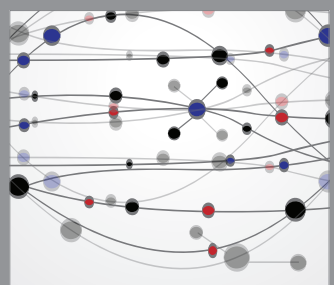

The Scientific World Journal
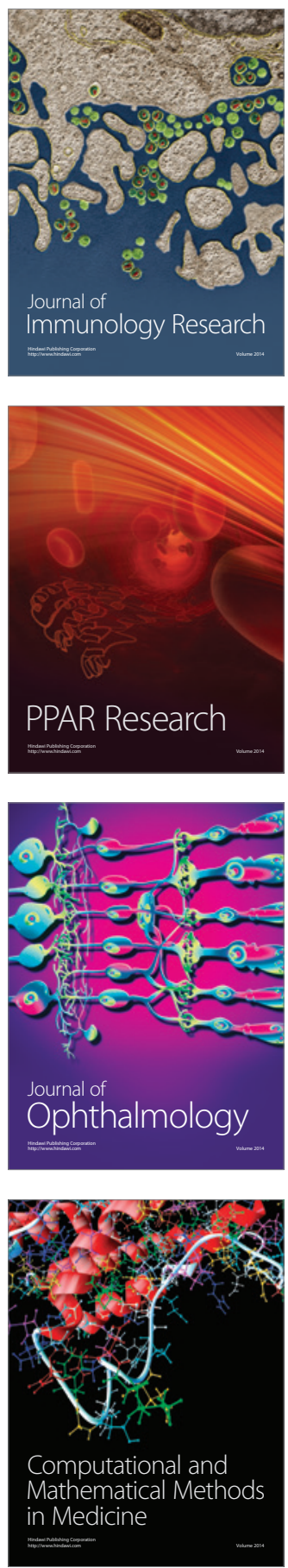

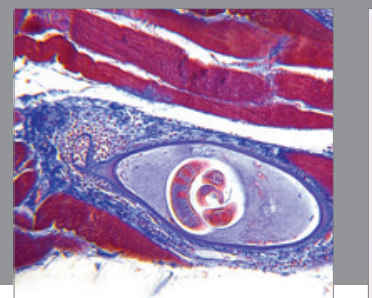

Gastroenterology

Research and Practice
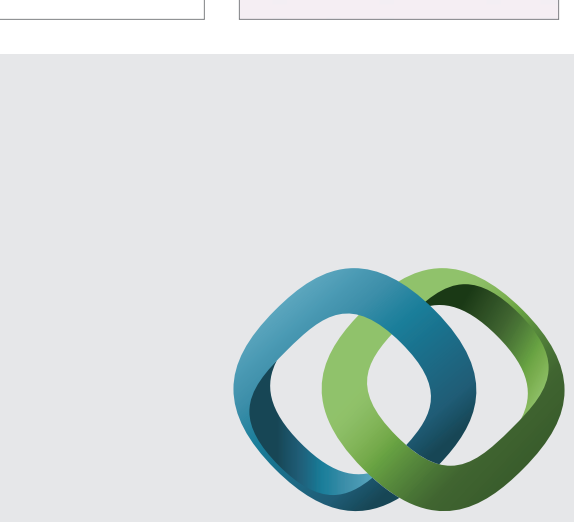

\section{Hindawi}

Submit your manuscripts at

http://www.hindawi.com
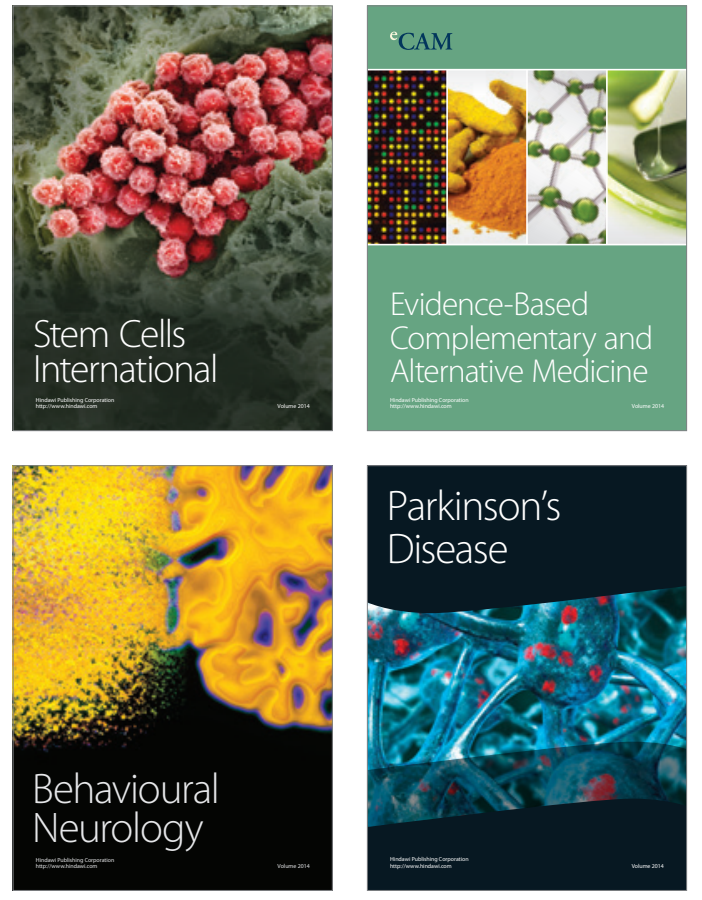
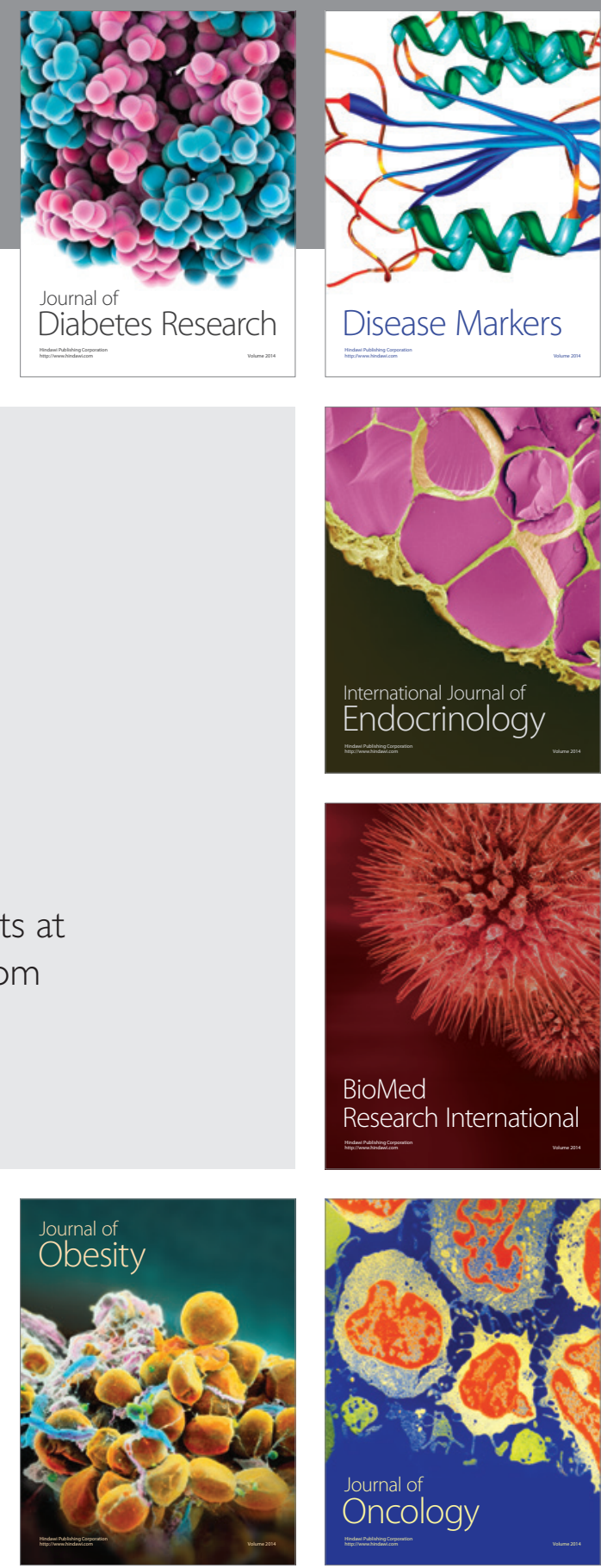

Disease Markers
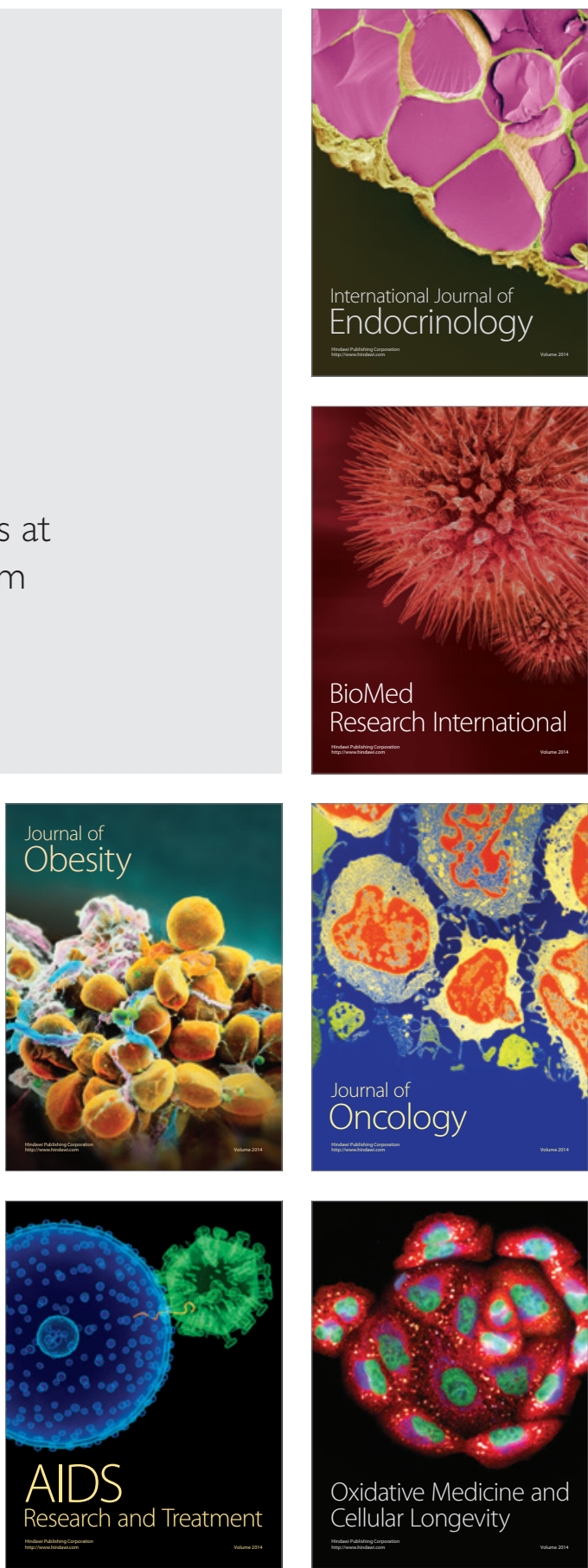